\title{
Pemberdayaan Masyarakat Kawasan Konservasi Kramat, Bedil, dan Temudong melalui Pengembangan Ekowisata Bahari dan Budi Daya Rumput Laut
}

\section{(Community Empowerment of Kramat, Bedil, and Temudong Conservation Areas through the Development of Marine Ecotourism and Seaweed Cultivation)}

\author{
Dedi Syafikri' ${ }^{1}$, Siti Nurwahidah ${ }^{2}$, Neri Kautsari ${ }^{{ }^{*}}$ \\ 1 Program Studi Manejemen Sumberdaya Perairan, Fakultas Peternakan dan Perikanan, Universitas Samawa, \\ Jalan By Pass Sering, Sumbawa Besar, Nusa Tenggara Barat 84313. \\ 2 Program Studi Agribisnis, Fakultas Pertanian, Universitas Samawa, Jalan By Pass Sering, Sumbawa Besar, \\ Nusa Tenggara Barat 84313 \\ *Penulis Korespondensi: nerikautsari040185@gmail.com \\ Diterima Agustus 2018/Disetujui Desember 2018
}

\begin{abstract}
ABSTRAK
Gugusan Pulau Kramat, Bedil, dan Temudong (KBT) merupakan Kawasan Konservasi Perairan (KKP) yang berada di Kabupaten Sumbawa tepatnya di Desa Labuhan Bajo. Permasalahan utama dalam kegiatan konservasi ialah adanya pelarangan penangkapan ikan di sebagian zona konservasi sehingga menyebabkan berkurangnya luasan daerah tangkapan yang secara langsung berdampak pada penurunan pendapatan masyarakat. Oleh karena itu, sebagai upaya menanggulangi permasalahan tersebut perlu optimalisasi pemanfaatan zona lainnya yang ada di kawasan konservasi. Salah satu zona kawasan konservasi yang belum termanfaatkan adalah zona perikanan berkelanjutan dan zona wisata. Zona ini memiliki potensi untuk ekowisata dan budi daya rumput laut, namun sebagian besar masyarakat belum memiliki pengetahuan dan keterampilan dalam pengembangan ekowisata maupun budi daya rumput laut. Program pengabdian kepada masyarakat ini bertujuan untuk melatih dan mendampingi masyarakat dalam mengintegrasikan ekowisata dengan budi daya rumput laut di zona perikanan berkelanjutan sehingga dapat menjadi mata pencaharian alternatif bagi masyarakat sekitar. Target yang ingin dicapai dalam kegiatan ini ialah tersedianya mata pencaharian alternatif bagi masyarakat di kawasan konservasi berbasis integrasi ekowisata dan budi daya rumput laut, peningkatan pendapatan masyarakat, dan terbangunnya persepsi yang baik terhadap kegiatan konservasi. Metode yang digunakan dalam kegiatan pengabdian ini adalah penyuluhan, pelatihan, dan pendampingan tentang pengembangan ekowisata bahari dan budi daya rumput laut Eucheuma cottonii di zona perikanan berkelanjutan. Hasil dari kegiatan ini adalah berkembangnya ekowisata bahari di KKP KBT yang dibuktikan dengan peningkatan jumlah pengunjung (wisatawan) sebesar tiga kali lipat dari sebelumnya, tersedianya mata pencaharian alternatif masyarakat melalui penyewaan perahu, serta peningkatan pengetahuan dan keterampilan masyarakat dalam budi daya rumput laut.
\end{abstract}

Kata kunci: budi daya rumput laut, ekowisata bahari, KKN KBT, pemberdayaan masyarakat

\begin{abstract}
Kramat, Bedil, and Temudong (KBT) islands are watershed conservation areas located in Sumbawa Regency precisely in Labuhan Bajo Village. The main problem is the prohibition of fishing in some conservation zones, thereby reducing the area of fishing. Reduced of catchment area directly affects the decrease in catches and community income. Therefore, as an effort to overcome these problems, it is necessary to optimize the utilization of other zones in the conservation area. Sustainable fisheries zones and tourism zones are zones that have not been optimally utilized. This zones has the potential for ecotourism and seaweed cultivation, but most people do not have the knowledge and skills in the development of ecotourism and seaweed cultivation. The program aims to train and assist the community in integrating ecotourism with seaweed cultivation in sustainable fisheries zones, so that it can be an alternative livelihood for the local community. the program has outcomes that consist of: the availability of alternative livelihoods for people in conservation areas based on the integration of ecotourism and seaweed cultivation, increasing community income, and building positive community perceptions for conservation activities. The method used is counseling, training and mentoring on the development of marine ecotourism and Eucheuma cottonii seaweed cultivation in the sustainable fishing zone. The results of this activity are the development of marine ecotourism in the KBT MPA as evidenced by an
\end{abstract}


increase in the number of visitors (tourists) three times more than before, the availability of alternative livelihoods of the community through boat rentals and increased knowledge and skills of the community in seaweed cultivation.

Keywords: community empowerment, KKN KBT, marine ecotourism, seaweed cultivation

\section{PENDAHULUAN}

Desa Labuhan Bajo terletak di Kecamatan Utan, Kabupaten Sumbawa merupakan desa pesisir yang wilayah perairannya masuk ke dalam Kawasan Konservasi Laut (KKP) gugusan Pulau Kramat, Bedil, dan Temudong (KBT). KKP tersebut dibentuk oleh Pemerintah Kabupaten Sumbawa dengan tujuan mewujudkan sumber daya ikan dan lingkungan yang berkelanjutan, sehingga KKP KBT dibagi menjadi tiga zona pengelolaan, yaitu zona inti (100 ha), zona pemanfaatan terbatas/pariwisata (650 ha), dan zona perikanan berkelanjutan (1.250 ha) (DKP Kabupaten Sumbawa 2014). Zonasi tersebut menyebabkan adanya aturan dan kebijakan baru yang diterapkan kepada masyarakat di sekitar kawasan konservasi. Salah satu aturannya ialah pelarangan penangkapan ikan serta kegiatan eksploitasi lainnya di zona inti dan zona pemanfaatan terbatas. Hal tersebut secara langsung menyebabkan berkurangnya luasan daerah tangkapan nelayan Desa Bajo. Penurunan luasan daerah tangkapan secara tidak langsung menyebabkan jumlah tangkapan berkurang yang pada akhirnya memengaruhi jumlah pendapatan nelayan Desa Labuhan Bajo. Hasil wawancara dengan masyarakat setempat menunjukkan bahwa sebagian masyarakat memiliki persepsi yang kurang baik terhadap aturan tersebut karena dianggap kurang memiliki peran dalam meningkatkan pendapatan masyarakat.

Sebagian besar masyarakat (nelayan) Desa Labuhan Bajo menggantungkan perekonomiannya pada kegiatan penangkapan ikan. Ketergantungan ini juga tergambar dari perilaku atau kebiasaan nelayan Desa Labuhan Bajo yang menganggur jika sudah tiba musim angin "barat" (angin kencang). Kondisi tersebut berdampak pada kurang dan bahkan tidak adanya pendapatan (pemasukan) selama musim tersebut. Ketergantungan terhadap kegiatan menangkap ikan ini disebabkan kurangnya pengetahuan dan keterampilan nelayan dalam memanfaatkan potensi sumber daya lainnya. Selain itu, wilayah Desa Labuhan Bajo hanya terdiri dari tanah kering yang tidak bisa dimanfaatkan untuk kegiatan pertanian. Menurut data statistik Kabupaten Sumbawa (2016), luas tanah kering di
Labuhan Bajo adalah 1.967 ha (90\% dari luas wilayah).

Salah satu potensi sumber daya alam Desa Labuhan Bajo yang belum termanfaatkan oleh nelayan setempat ialah potensi perairan dan panorama alam yang indah. Potensi tersebut terdapat di zona perikanan berkelanjutan dan zona pariwisata. Berdasarkan fungsi pemanfaatan yang diperbolehkan oleh Pemerintah Daerah Sumbawa yang dituangkan dalam Surat Keputusan (SK) Bupati Sumbawa no 570 Tahun 2014, zona tersebut dapat difungsikan untuk ekowisata, penangkapan, dan budi daya ramah lingkungan seperti budi daya rumput laut. Sampai saat ini zona tersebut belum dimanfaatkan secara optimal oleh masyarakat baik untuk ekowisata maupun budi daya. Hal ini disebabkan karena sebagian besar masyarakat belum memiliki pengetahuan dan keterampilan dalam pengelolaan ekowisata ataupun budi daya rumput laut.

Berdasarkan permasalahan tersebut, maka dibutuhkan transfer ilmu dalam bentuk pelatihan dan pemdampingan kepada masyarakat. Transfer ilmu pada kegiatan ini dilakukan dalam bentuk Kuliah Kerja Nyata Program Pemberdayaan Kepada Masyarakat (KKN-PPM). Tujuan dari kegiatan ini adalah untuk melakukan pemberdayaan masyarakat dalam memanfaatan zona perikanan berkelanjutan dan zona ekowisata sebagai lokasi pengembangan ekowisata bahari dan budi daya rumput laut, sehingga dapat dijadikan sebagai solusi dalam meningkatkan pendapatan masyarakat sekitar dan mengurangi persepsi negatif masyarakat terhadap kegiatan konservasi.

\section{METODE PELAKSANAAN KEGIATAN}

\section{Waktu dan Lokasi Kegiatan}

Kegiatan pengabdian dalam bentuk Kuliah Kerja Nyata (KKN) ini dilaksanakan pada bulan Mei-Juli 2018. Lokasi kegiatan adalah di sekitar KKP gugusan KBT tepatnya di Desa Labuhan Bajo. Secara administratif wilayah ini masuk dalam wilayah Desa Labuhan Bajo, Kecamatan Utan, Kabupaten Sumbawa (Gambar 1). 

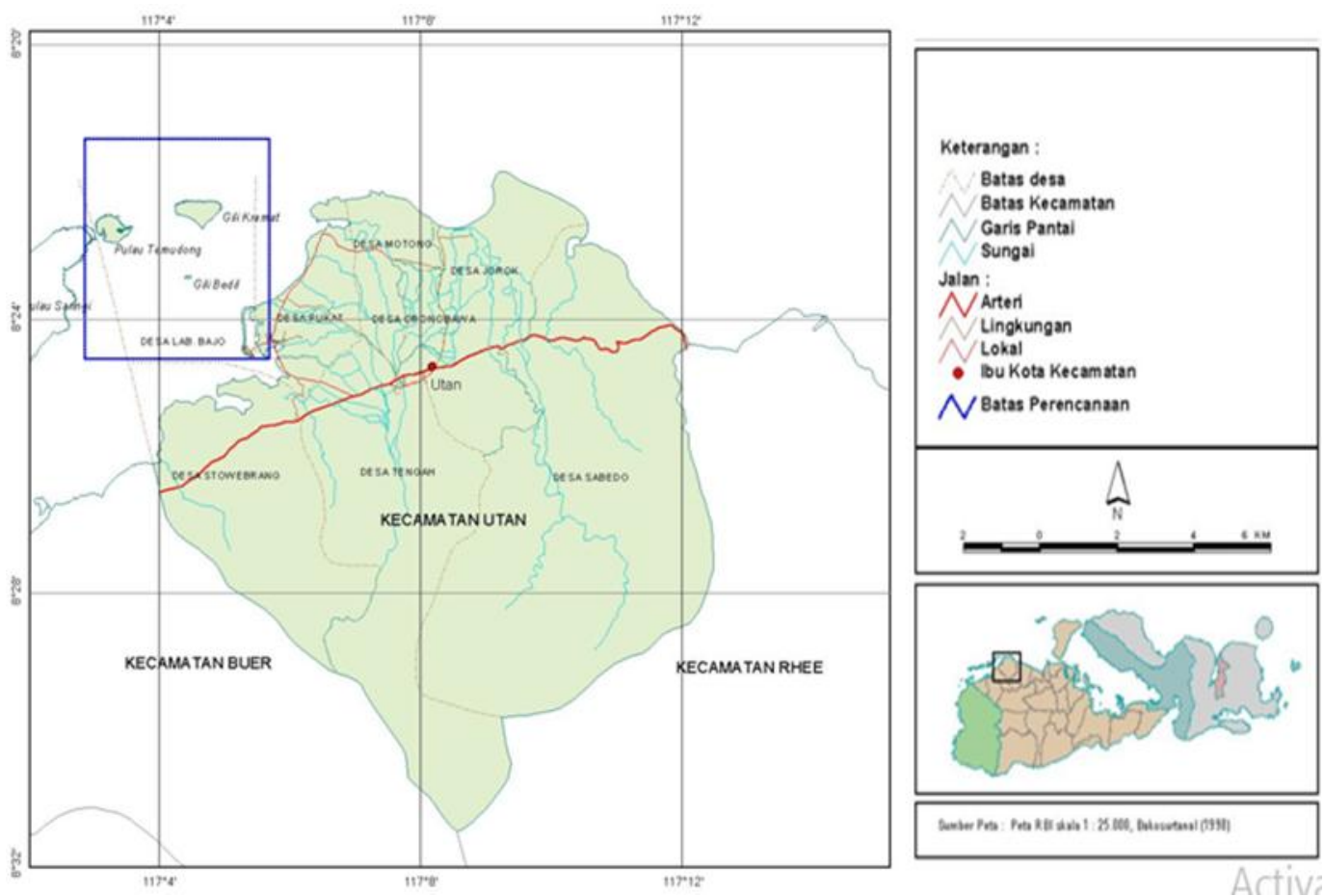

Gambar 1 Peta lokasi kegiatan pengabdian kepada masyarakat.

\section{Kelompok Sasaran dan Target Kegiatan}

Kegiatan pengabdian kepada masyarakat ini merupakan bagian dari KKN mahasiswa sehingga terdapat dua kelompok sasaran, yaitu mahasiswa dan kelompok masyarakat Desa Labuhan Bajo. Target kegiatan KKN-PPM untuk kelompok mahasiswa adalah membentuk semangat kerja sama, meningkatkan sifat kepemimpinan, meningkatkan sifat empati, dan kepedulian terhadap persoalan masyarakat serta melatih mahasiswa dalam mengaplikasikan ilmu yang diperoleh selama perkuliahan. Target yang ingin dicapai untuk kelompok masyarakat umum dan kelompok pemuda Desa Labuhan Bajo adalah masyarakat dan kelompok pemuda mampu mengembangkan potensi wilayahnya melalui pengembangan ekowisata bahari dan budi daya rumput laut di zona perikanan berkelanjutan sehingga ke depannya dapat meningkatkan pendapatan masyarakat dan menyukseskan program konservasi.

\section{Metode dan Tahapan Kegiatan}

Metode yang digunakan dalam kegiatan ini ialah metode partisipasi aktif. Partisipasi aktif yang dimaksud dalam kegiatan ini ialah kelompok masyarakat sasaran berperan aktif pada seluruh tahapan kegiatan. Program ini terdiri dari beberapa tahapan, yaitu 1) Sosialisasi; 2) Penyuluhan; 3) Pelatihan dan pendampingan pengembangan ekowisata bahari; 4) Budi daya dan pengolahan rumput laut; dan 5) Evaluasi hasil kegiatan dilakukan melalui wawancara terhadap kelompok masyarakat. Secara spesifik pelatihan yang diberikan kepada kelompok masyarakat sasaran terdiri atas: 1) Pelatihan pemanfaatan sampah dalam menunjang dan mengembangkan ekowisata bahari; 2) Pelatihan diving dan penentuan titik penyelaman bagi calon pemandu wisata; 3) Pelatihan strategi promosi dan pembuatan video ekowisata bahari; 4) Pelatihan budi daya rumput laut dengan metode patok dasar; dan 5) Pelatihan pengolahan rumput laut dan mangrove.

\section{HASIL PELAKSANAAN KEGIATAN}

\section{Sosialisasi Kegiatan Pengabdian kepada Pemerintah Desa}

Hasil yang diperoleh dari sosialisasi ini ialah pemerintah menerima dan memberi dukungan terhadap rencana program pengembangan ekowisata bahari dan budi daya rumput laut di zona perikanan. Hal tersebut dibuktikan dengan adanya kesepakatan mengenai waktu pelaksanaan dan kelompok masyarakat yang akan dilibatkan. Waktu pelaksanaan yang disepakati dalam kegiatan sosialisasi dilaksanakan pada bulan Mei-Juni tahun 2018. Kelompok masyarakat yang dilibatkan secara aktif pada kegiatan ini adalah kelompok pemuda Desa Labuhan Bajo yang beranggotakan 18 orang. Bentuk dukungan lainnya yang diberikan oleh pemerintah Desa 
Labuhan Bajo ialah penyediaan posko atau tempat tinggal mahasiswa selama kegiatan pengabdian berlangsung.

\section{Penyuluhan Pemanfaataan Zona Perikanan Berkelanjutan}

Tujuan utama penyuluhan pada kegiatan ini ialah memberikan pengetahuan secara teoritis atau pengetahuan awal kepada kelompok masyarakat sasaran mengenai kesadaran pada lingkungan, pemanfaatan zona perikanan berkelanjutan lokasi ekowisata dan budi daya rumput laut. Penyuluhan yang dilakukan pada kegiatan ini diharapkan mampu meningkatkan pengetahuan masyarakat mengenai pemanfaatan zona perikanan berkelanjutan dan zona ekowisata sebagai lokasi ekowisata bahari dan budi daya rumput laut yang selanjutnya dapat meningkatkan pendapatan masyarakat dan mengubah persepsi negatif masyarakat pada konservasi.

Peningkatan pengetahuan masyarakat melalui penyuluhan diharapkan masyarakat dapat berpartisipasi secara aktif dalam pembangunan ekowisata bahari dan budi daya rumput laut di kawasan konservasi KBT. Zhang dan Lei (2012) menyatakan bahwa partisipasi masyarakat lokal dalam ekowisata dapat dimotivasi dengan meningkatkan pemahaman masyarakat lokal mengenai masalah lingkungan, ekowisata, dan melibatkannya secara aktif dalam rencana pengembangan lingkungan. Kurangnya informasi mengenai masalah lingkungan memiliki dampak negatif terhadap lingkungan setempat. Pengetahuan lingkungan merupakan variabel penting yang memengaruhi tingkat keterlibatan masyarakat (Barr \& Gilg 2007). Oguz et al. (2011) menyatakan bahwa individu yang mempelajari masalah lingkungan lebih cenderung bertindak secara ekologis. Vicente-Molina et al. (2013) menemukan bahwa pengetahuan memiliki pengaruh yang signifikan pada perilaku dan sikap peduli pada lingkungan. Oleh karena itu, kegiatan penyuluhan sangat penting dilakukan sebagai upaya untuk melibatkan masyarakat dalam program pengembangan ekowisata dan budi daya rumput laut.

Kegiatan penyuluhan ini dibuka oleh Kepala Desa Labuhan Bajo dan ketua pelaksana kegiatan. Pada kegiatan ini disampaikan empat materi atau bahasan, yaitu 1) Peran konservasi dalam keberlajutan ekologi, ekonomi, dan sosial; 2) Pengembangan ekowisata bahari di zona perikanan berkelanjutan; 3) Pengolahan sampah dalam mendukung pengembangan ekowisata bahari; dan 4) Teknik budi daya rumput laut di kawasan konservasi. Penyampaian materi dilakukan oleh empat pemateri, yaitu ketua dan anggota pelaksana kegiatan (menyampaikan materi peran konservasi dan pengembangan ekowisata bahari), penyuluh dari Dinas Kelautan dan Perikanan Kabupaten Sumbawa (menyampaikan materi budi daya), dan salah satu akademisi dalam bidang pengolahan sampah (menyampaikan materi pengolahan sampah). Total peserta yang ikut dalam kegiatan ini adalah sebanyak 30 orang yang merupakan kelompok pemuda Desa Labuhan Bajo dan masyarakat umum. Kegiatan ini dilaksanakan selama tiga jam, yaitu dari pukul 09.00-12.00 WITA. Suasana kegiatan penyuluhan dan seminar di aula kantor Desa Labuhan Bajo terlihat pada Gambar 2.

Pada kegiatan ini juga dilakukan diskusi (tanya jawab) antara pemateri dan peserta kegiatan. Sebagian besar kelompok masyarakat aktif dalam bertanya terutama tentang budi daya rumput laut. Hasil dari kegiatan ini menunjukkan bahwa sebelum adanya penyuluhan, 95\% kelompok masyarakat sasaran belum mengetahui cara pemanfaatan kawasan konservasi baik dalam hal pengembangan ekowisata bahari maupun budi daya ramah lingkungan (budi daya rumput laut). Hasil evaluasi akhir terhadap pemahaman kelompok masyarakat sasaran adalah 85\% telah mengetahui secara teoritis mengenai pemanfaatan zona perikanan berkelanjutan untuk pengembangan ekowisata bahari dan budi daya rumput laut. Tingkat pemahaman ini diperoleh dari hasil tanya jawab dan diskusi dengan kelompok masyarakat sasaran.

\section{Pelatihan dan Pendampingan Pengembangan Ekowisata Bahari}

Joshi (2011) mendefenisikan ekowisata sebagai perjalanan dan kunjungan alam yang bertanggung jawab terhadap lingkungan untuk

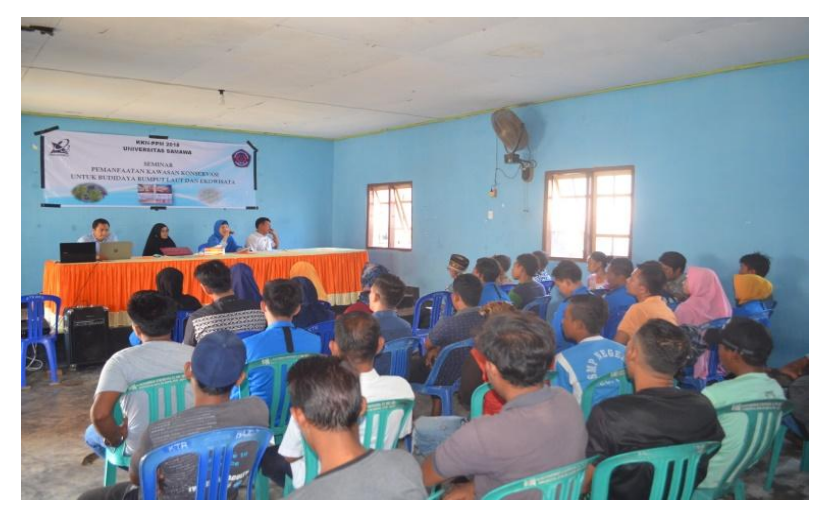

Gambar 2 Suasana kegiatan penyuluhan dan seminar di aula kantor Desa Labuhan Bajo. 
menikmati dan menghargai alam (fitur budaya yang menyertainya, baik dulu maupun sekarang), mempromosikan konservasi, memiliki dampak pengunjung yang rendah dan menyediakan aspek sosial-ekonomi yang menguntungkan bagi masyarakat lokal. TIES (2015) menambahkan bahwa ekowisata merupakan suatu bentuk perjalanan yang bertanggung jawab ke wilayahwilayah yang masih alami dengan tujuan konservasi atau melestarikan lingkungan dan memberi penghidupan pada penduduk lokal serta melibatkan unsur pendidikan.

Pada kegiatan ini, pengembangan ekowisata bahari dilakukan berdasarkan konsep community based tourism, yaitu suatu pendekatan pariwisata yang menekankan pada partisipasi masyarakat lokal baik yang terlibat langsung maupun yang tidak langsung (Depbudpar-WWF 2009). Damanik dan Weber (2006) menambahkan bahwa defenisi pariwisata berbasis masyarakat adalah aktivitas ekonomi penting yang jika dikembangkan dengan tepat dapat mengatasi sejumlah tantangan pembangunan, termasuk pengurangan kemiskinan, pengembangan ekonomi lokal, perdamaian, keselarasan masyarakat, dan manajemen sumber daya alam serta lingkungan yang berkesinambungan. Liu et al. (2014) menyatakan bahwa partisipasi dari masyarakat lokal dalam ekowisata membantu membangun keberlanjutan ekowisata jangka panjang dan memastikan penggunaan dan pengelolaan sumber daya alam yang berkelanjutan. Berdasarkan hal tersebut maka dapat diartikan bahwa ekowisata berbasis masyarakat memiliki multi peranan dalam kehidupan manusia baik dalam perbaikan lingkungan maupun peningkatan kesejahteraan masyarakat sekitar. Oleh karena itu, konsep ekowisata berbasis masyarakat diterapkan pada program ekowisata di KKP KBT.

Pemberdayaan masyarakat dalam kegiatan pengembangan ekowisata bahari di kawasan konservasi perairan KBT dilakukan dengan cara melibatkan masyarakat secara aktif dalam pelatihan pengelolaan ekowisata, mulai dari kegiatan pengolahan sampah, penentuan spot diving, hingga pelatihan peyelaman bagi kelompok calon pemandu wisata. Secara garis besar, pelatihan ini dibagi menjadi dua bagian, yaitu pelatihan pengolahan sampah dan pelatihan pengembangan ekowisata selam (diving).

- Pengembangan ekowisata bahari melalui penanggulangan dan pemanfaatan sampah Pelatihan dan pengembangan ekowisata bahari diawali dengan membentuk kelompok pemuda yang akan dilatih dan dijadikan sebagai pengelola ekowisata di kawasan konservasi. Kelompok pemuda yang terbentuk beranggotakan 15 orang yang berasal dari tiga dusun di Desa Labuhan Bajo. Program awal yang dilakukan pada kegiatan ini ialah penanggulangan sampah botol plastik yang berada di sekitar kawasan konservasi. Penanggulangan sampah botol plastik ini dilakukan sebagai upaya mengurangi jumlah sampah botol plastik yang dapat merusak lingkungan dan ekosistem sekitar terutama ekosistem perairan. Sampah plastik dapat mengganggu organisme perairan baik secara langsung maupun tidak langsung. Oleh karena itu, sampah plastik harus ditangani secara tepat dan cermat. Tujuan dari kegiatan ini ialah menanggulangi sampah botol plastik melalui pemanfaatannya sebagai karya seni yang dapat meningkatkan keindahan wisata sehingga dapat dijadikan sebagai daya tarik bagi wisatawan. Kegiatan ini dimulai dengan pengumpulan sampah botol plastik di sekitar perairan Desa Labuhan Bajo.

Kegiatan selanjutnya ialah pemanfaatan sampah sebagai karya seni yang akan dipasang di Pulau Bedil (bagian kawasan KKP KBT). Karya seni yang dibuat berupa spot foto, ayunan, dan pohon harapan. Total pengerjaan dari pengumpulan sampah hingga pemasangan dilakukan selama kurang lebih satu bulan. Proses pelatihan dan pembuatan karya seni dari sampah terlihat pada Gambar 3. Kelompok pemuda dan mahasiswa selanjutnya memasang karya seni tersebut di kawasan zona perikanan berkelanjutan tepatnya di Pulau Bedil. Lokasi penempatan spot selfi ini ditentukan berdasarkan hasil diskusi antara mahasiswa dan kelompok pemuda Desa Labuhan Bajo serta arahan pemerintah dan masyarakat.

Beberapa hasil yang dicapai dalam kegiatan ini adalah 1) Terbentuknya empat macam karya seni yang terbuat dari sampah botol plastik; 2) Berkurangnya jumlah sampah botol plastik di sekitar kawasan konservasi; 3) Meningkatnya keterampilan masyarakat dalam pengolahan sampah; dan 4) Secara tidak langsung mengurangi dampak limbah botol plastik di perairan.

\section{- Pengembangan wisata bahari melalui ekowisata diving}

Kegiatan pengembangan ekowisata bahari dilanjutkan dengan memfokuskan kegiatan pengembangan ekowisata diving di zona perikanan berkelanjutan. Pemanfaatan zona perikanan berkelanjutan sebagai ekowisata diving didasarkan 

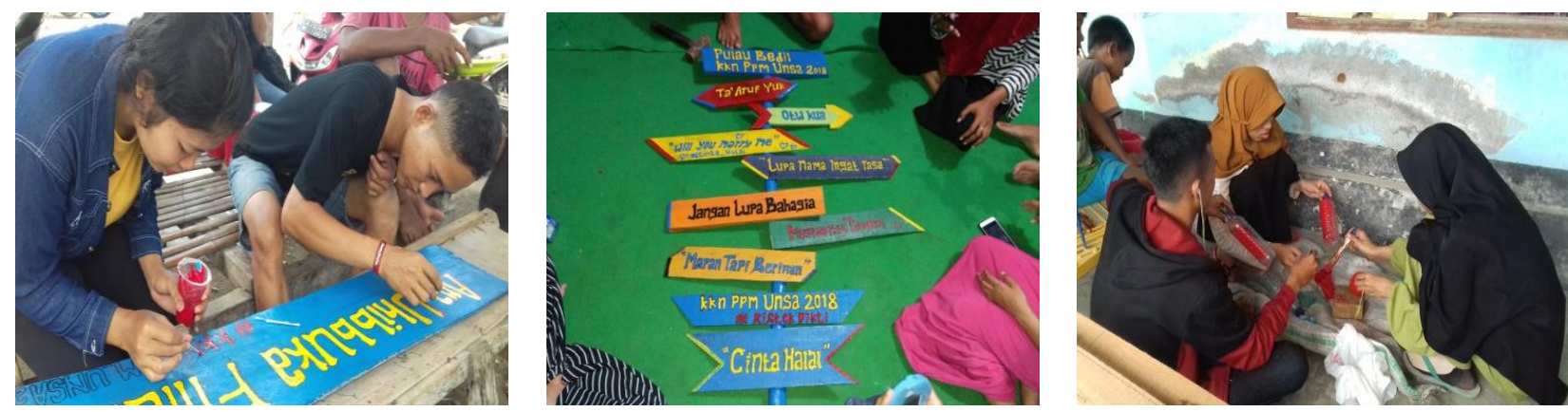

Gambar 3 Proses pelatihan dan pembuatan karya seni dari sampah.

pada potensi panorama bawah laut yang ada di kawasan konservasi KBT. Menurut Bato et al. (2013) pemanfaatan suatu lokasi harus disesuaikan dengan potensi yang dimiliki sehingga pengelolaannya lebih optimal dan terukur. Hal ini sejalan yang dikatakan oleh Collins (2008) bahwa kesesuaian suatu kawasan merupakan kecocokan suatu kawasan untuk penggunaan tertentu, sehingga pemanfaatannya dapat disesuaikan dengan kondisi atau potensi yang dimilikinya.

Kegiatan pengembangan ekowisata bahari dilakukan melalui beberapa tahap pelatihan. Pelatihan pertama yang diberikan kepada kelompok pemuda adalah teknik penyelaman yang baik tanpa merusak lingkungan. Pelatihan kedua adalah pemetaan titik penyelaman melalui metode pengamatan panorama alam bawah laut. Pelatihan ketiga adalah pengenalan organisme laut dan pelatihan keempat adalah menjadi pemandu wisata.

Kegiatan pengenalan bawah laut dan pelatihan penyelaman dilakukan selama kurang lebih tiga hari. Fokus pelatihan yang diberikan pada kegiatan ini ialah pelatihan menjadi pemandu diving yang baik. Tujuan dari serangkaian kegiatan ini ialah agar kelompok pemuda dapat memperoleh pendapatan dari profesi menjadi pemandu diving serta sebagai wadah menambah wawasan dan pengetahuannya dalam teknik diving.

Hasil dari pelatihan dan pendampingan ini ialah kelompok pemuda telah menetapkan titik penyelaman yang sesuai untuk kegiatan ekowisata selam. Penetapan titik penyelaman ini didasarkan pada tingkat kecerahan perairan, tutupan karang, dan kelimpahan ikan karang. Semakin cerah suatu perairan maka keindahan bawah laut yang dapat dinikmati wisatawan akan semakin tinggi. Kawasan wisata diving dengan kecerahan $80-100 \%$ adalah lokasi yang sangat sesuai untuk wisata diving. Arifin (2008) menyatakan bahwa kawasan terumbu karang dengan kecerahan $50-80 \%$ adalah sesuai untuk wisata diving, sedangkan kawasan terumbu karang yang nilai kecerahannya kurang dari $20 \%$ dianggap tidak sesuai, persentase tutupan komunitas karang, jenis lifeform, dan jenis ikan karang mempunyai nilai daya tarik bagi wisatawan karena memiliki variasi morfologi dan warna yang menarik. Berdasarkan hal tersebut maka dari pemantauan dengan kelompok masyarakat, kawasan zona perikanan berkelanjutan di KBT sangat menunjang dalam pengembangan ekowisata bahari.

Pada akhir kegiatan dilakukan evaluasi tentang tingkat pemahaman kelompok pemuda terhadap kegiatan. Hasil evaluasi menunjukkan bahwa 85\% kelompok pemuda yang ikut serta dalam kegiatan telah mengetahui dengan jelas mengenai teknik penyelaman dan penentuan titik penyelaman. Hasil evaluasi juga menunjukkan bahwa kelompok masyarakat sasaran berperan aktif dalam seluruh rangkaian kegaiatan. Hal ini dibuktikan dengan tingkat kehadiran dan keaktifannya pada seluruh rangkaian kegiatan. Menurut Hardianti et al. (2015), tingkat partisipasi masyarakat dalam suatu kegiatan pembangunan dapat dilihat dari beberapa indikator, yaitu tingkat kehadiran dan keaktifan dalam kegiatan. Hal ini juga diungkapkan oleh Huraira (2008) dan Laksana (2013) bahwa salah satu bentuk partisipasi masyarakat adalah ikut serta dalam memberikan sumbangan ide ataupun tenaga.

\section{- Promosi ekowisata bahari melalui media online}

Sebagai upaya memperkenalkan hasil pengembangan ekowisata bahari kepada seluruh masyarakat maka dilakukan promosi ekowisata melalui beberapa strategi di antaraya pembuatan video, promosi melalui media sosial (facebook, instagram, whatsaap, dan youtube). Pelatihan ini berlangsung hingga satu minggu. Pelatihan juga dilakukan tekait dengan penetapan harga sewa perahu dan lainnnya. Tujuan dari kegiatan 
pelatihan ini ialah agar kelompok pemuda masyarakat Labuhan Bajo dapat secara mandiri melakukan strategi promosi ekowisata yang ada di kawasannya. Gambar 4 menunjukkan beberapa bentuk promosi melaui facebook dan youtube.

Hasil dari kegiatan pelatihan ini ialah terbentuknya satu video promosi ekowisata bahari yang disebarkan melalui akun facebook, youtube, dan whatsapp. Selain dalam bentuk produk video, kegiatan ini juga menghasilkan peningkatan keterampilan kelompok pemuda dalam pembuatan video dan starategi promosi.

\section{- Evaluasi program pengembangan ekowisata bahari}

Evaluasi program pengembangan ekowisata bahari bertujuan untuk melihat capaian program. Evaluasi ini dilakukan dengan melihat jumlah wisatawan yang berkunjung ke wisata bahari di kawasan konservasi KBT. Hasil evaluasi menunjukkan bahwa jumlah wisatawan atau pengunjung meningkat secara drastis jika dibandingkan tahun-tahun sebelumnya. Pada tahun-tahun sebelumnya, keindahan alam di kawasan ini belum diketahui oleh masyarakat banyak sehingga sangat minim pengunjungnya. Pemantauan jumlah pengunjung dilakukan melalui beberapa cara, yaitu pemantauan secara langsung oleh kelompok pemuda Desa Labuhan Bajo dan pemantaun dilakukan oleh tim dan mahasiswa melalui media sosial.

Selain evaluasi terhadap tingkat partisipasi masyarakat, juga dilakukan evaluasi pada dampak perekonomian masyarakat setempat. Setyawan dan Satria (2017) menyatakan bahwa pengelolaan ekowisata yang baik salah satunya dapat dicirikan dengan meningkatnya penda- patan masyarakat lokal. Secara umum dampak ekonomi yang dirasakan berupa peningkatan pendapatan (positif). Hasil penelitian Bato et al. (2013) menunjukkan bahwa ekowisata yang dilakukan di Kawasan Konservasi Nusa Penida telah mampu meningkatkan pendapatan masyarakat sebesar 10-30\%. Penelitian Tafalas (2010) di Raja Ampat membuktikan adanya dampak positif dari kegiatan ekowisata pada perekonomian nelayan.

Pada kegiatan ini, evaluasi manfaat ekonomi pengembangan ekowisata dilakukan dengan wawancara pada kelompok masyarakat sasaran. Hasil wawancara menunjukkan bahwa kelompok masyarakat sasaran merasakan manfaat ekonomi setelah program berlangsung. Beberapa manfaat ekonomi yang dirasakan ialah peningkatan pendapatan kelompok melalui usaha jasa sewa perahu dan menjadi pemandu wisatawan baik lokal maupun mancanegara. Manfaat lainnya yang dirasakan adalah Desa Labuhan Bajo menjadi ramai karena pengunjung harus melalui Desa Labuhan Bajo untuk melakukan penyebrangan ke Pulau Bedil. Terkait dengan pendapatan yang diperoleh ataupun jumlah pengunjung yang datang ke lokasi belum terdata dengan baik, hal ini dikarenakan oleh kelompok pemuda atau masyarakat belum melakukan pencatatan jumlah pengunjung. Adanya peningkatan jumlah pendapatan dan jumlah pengunjung dapat ditinjau dari jumlah pengantaran pengunjung ke lokasi atau penyewaan perahu. Hasil wawancara dengan kelompok masyarakat menyatakan bahwa setelah adanya program tersebut, jumlah penyewaan perahu meningkat menjadi tiga kali lipat dalam sehari dan bisa mencapai lima kali lipat pada hari-hari libur.

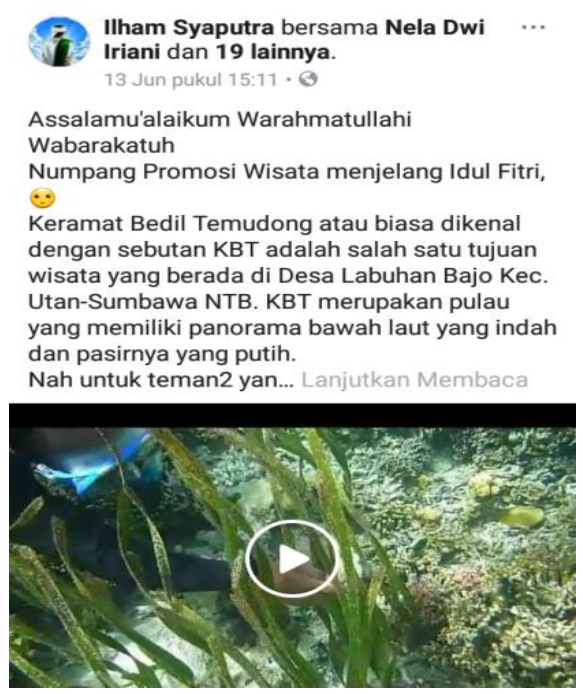

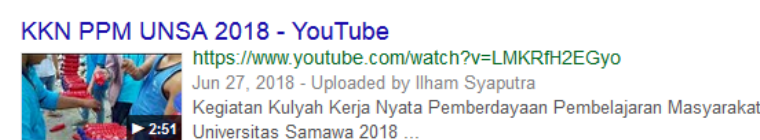

KKN PPM UNSA 2018 - YouTube

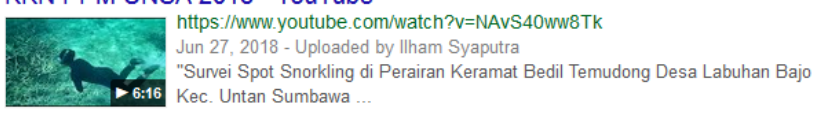

Wisata Pulau Bedil Desa Labuhan Bajo "KKN PPM UNSA 2018 ...

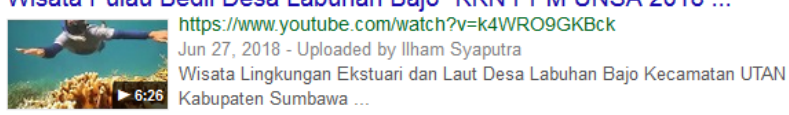

Selamat Menunaikan Ibadah Sholat Zuhur KKN PPM UNSA 2018 ...

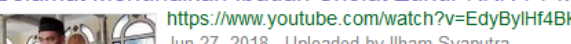

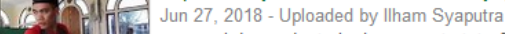
1.
$>$ 4:08
18. Illam Syaputra ...

Gambar 4 Beberapa bentuk promosi melaui facebook dan youtube. 
Peningkatan jumlah penyewaan perahu ini secara berkorelasi positif dengan peningkatan jumlah pendapatan, hal ini dikarenakan kelompok masyarakat memperoleh keuntungan dari penyewaan perahu dan menjadi pemandu wisata.

\section{Pelatihan dan Pendampingan Budi Daya Rumput Laut}

Secara teoritis teknik budi daya rumput laut ini telah disampaikan pada kegiatan seminar oleh pemateri dari Dinas Kelautan dan Perikanan Kabupaten Sumbawa. Secara praktik pelatihan ini dimulai dengan pelatihan pengenalan lokasi budi daya rumput laut yang tepat. Tujuan dari pelatihan ini adalah agar kelompok pemuda mampu menentukan tipe dan lokasi yang baik dalam kegiatan penanaman rumput laut. Beberapa hal yang dipraktikkan pada saat pelatihan pengenalan kualitas air di antaranya ialah pelatihan pengecekan substrat dasar perairan, arus perairan, dan tingkat serangan organisme pengganggu. Radiarta et al. (2004); Kautsari dan Ahdiansyah (2016) menyatakan bahwa kualitas air yang baik untuk budi daya rumput laut memiliki kisaran arus 0,20-0,30 $\mathrm{m} / \mathrm{dt}$, kecerahan perairan $>3 \mathrm{~m}$, suhu berkisar antara $26-31^{\circ} \mathrm{C}$, salinitas $28-31 \mathrm{ppt}$, oksigen terlarut $>5 \mathrm{mg} / \mathrm{L}$, $\mathrm{pH}$ berkisar antara 7,5-8, dan memiliki lokasi yang terlindung. Kautsari dan Syafikri (2017) menyatakan bahwa pelatihan pengamatan kualitas air dan daya dukung perairan untuk budi daya rumput laut sangat diperlukan karena keberhasilan budi daya sangat dipengaruhi oleh daya dukung dan kualitas perairan. Hal ini juga sesuai dengan pernyataan Munoz et al. (2004); Tewari et al. (2006); Radiarta (2013) yang menyatakan bahwa pemilihan lokasi merupakan kunci utama keberhasilan budi daya rumput laut.

Pelatihan dilanjutkan dengan pelatihan pemilihan bibit rumput laut yang baik serta cara pengikatan rumput laut pada tali ris (Gambar 5). Adapun kriteria bibit rumput laut yang dikategorikan baik dalam pelatihan mengacu pada Radiarta (2013), yaitu memiliki talus bercabang banyak, rimbun dan ujung-ujung talus agak runcing, dan bibit berumur antara 25-30 hari (WWF 2014). Pengikatan bibit dilakukan di tempat yang teduh di pinggir pantai, sehingga memudahkan untuk menyiram/membasahi bibit selama proses pengikatan. Berat bibit untuk masing-masing titik sekitar 50 g. Penanaman dilakukan pada hari yang sama setelah pengikatan bibit selesai dilakukan, sehingga rumput laut
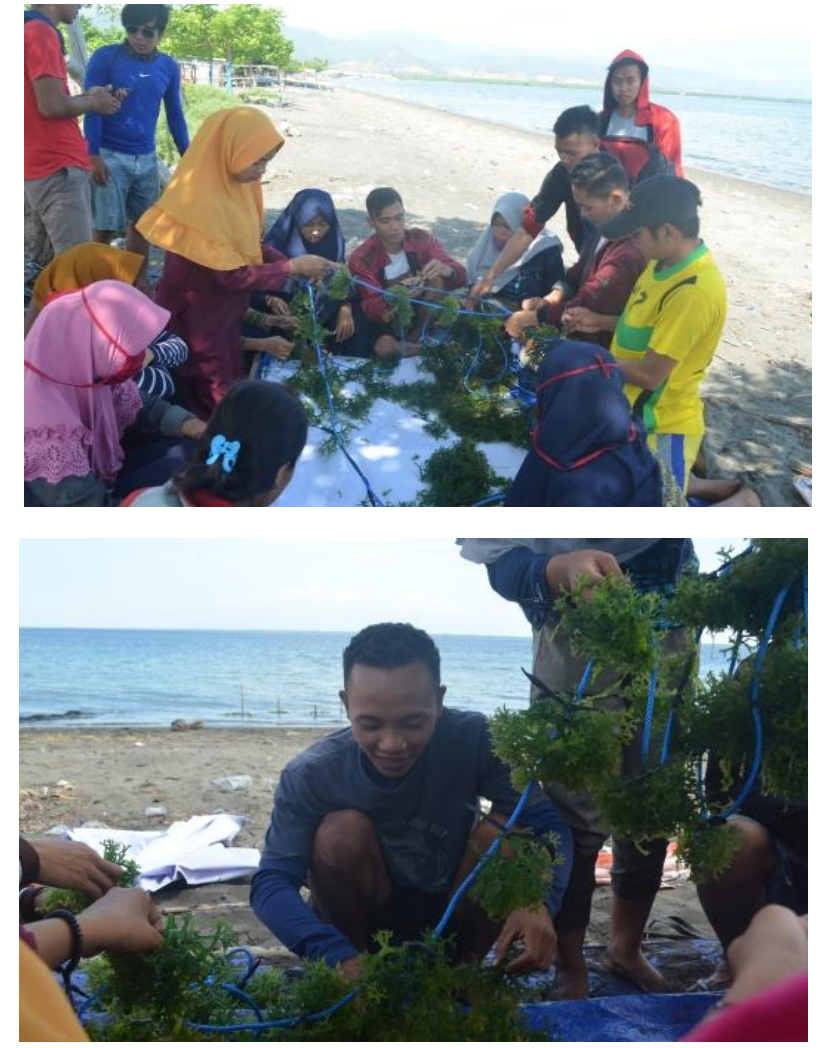

Gambar 5 Pelatihan pemilihan dan pengikatan bibit rumput laut.

masih dalam kondisi segar. Tujuan dari kegiatan ini adalah agar kelompok masyarakat sasaran mampu mengenal jenis bibit rumput laut yang baik untuk ditanam dan dikembangkan. Jenis rumput laut yang digunakan pada kegiatan ini ialah rumput laut jenis Euchema cotonii. Pemilihan jenis rumput laut tersebut karena jenis rumput laut ini memiliki harga cukup tinggi dibandingkan jenis lainnya dan merupakan jenis rumput laut yang masuk ke dalam program pengembangan pemerintah Kabupaten Sumbawa (Kautsari \& Syafikri 2017).

Pelatihan kemudian dilanjutkan dengan penanaman rumput laut. Metode penanaman yang digunakan pada pelatihan ini ialah metode lepas dasar sistem patok. Metode lepas dasar sistem patok merupakan cara penanaman rumput laut di atas dasar perairan (masih terendam air 20-50 $\mathrm{cm}$ pada saat surut terendah) dengan menggunakan tali yang diikatkan pada patok yang dipasang secara teratur. Pemilihan sistem lepas dasar pada kegiatan ini, salah satunya karena karakteristik substrat perairan yang berpasir sehingga memudahkan pemasangan patok. Patok atau kayu yang digunakan dalam pelatihan ini sebagian besar diperoleh dari masyarakat. Hal ini menunjukkan antusiasme masyarakat dan kelompok pemuda dalam hal budi daya rumput laut di kawasan konservasi. 
Kegiatan pelatihan budi daya rumput laut ini berlangsung selama kurang lebih tiga hari mulai dari kegiatan persiapan hingga kegiatan penanaman. Kegiatan monitoring dan perawatan rumput laut dilakukan selama satu bulan dengan frekuensi satu minggu sekali. Kelompok masyarakat yang terlibat dalam kegiatan ini sangat antusias dalam mengikuti keseluruhan proses kegiatan. Hal ini terlihat dari keterlibatannya yang selalu aktif dalam setiap kegiatan mulai dari persiapan bibit hingga penanaman rumput laut. Hasil dari kegiatan pelatihan dan pendampingan budi daya rumput laut ini ialah terbentuknya satu unit budi daya rumput laut dan peningkatan keterampilan masyarakat dalam budi daya rumput laut.

\section{SIMPULAN}

Kegiatan pengabdian kepada masyarakat ini telah mampu meningkatkatkan pengetahuan dan keterampilan masyarakat dalam pemanfaatan zona perikanan berkelanjutan sebagai lokasi ekowisata bahari dan budi daya rumput laut. Ekowisata bahari yang dikembangkan mampu menarik wisatawan yang secara langsung meningkatkan pendapatan melalui penyewaan perahu dan menjadi pemandu wisata. Kegiatan budi daya rumput laut yang dilakukan di Desa Labuhan Bajo belum memperlihatkan pengaruh terhadap peningkatan pendapatan masyarakat karena hasil budi daya belum sampai pada tahap pemasaran.

\section{UCAPAN TERIMA KASIH}

Ucapan terima kasih disampaikan kepada Kementerian Riset dan Pendidikan Tinggi (Kemenristekdikti) yang telah mendanai seluruh rangkaian program Kuliah Kernya Nyata Pemberdayaan Masyarakat (KKN-PPM). Ucapan terima kasih juga disampaikan kepada Lembaga Penelitian dan Pengabdian Kepada Masyarakat (LPPM) Universitas Samawa, pimpinan Universitas Samawa, Pemerintah Desa Labuhan Bajo, Dinas Kelautan dan Perikanan Kabupaten Sumbawa, CV Hafillah dan kelompok pemuda masyarakat Desa Labuhan Bajo yang telah mendukung dan mensukseskan program dari awal hingga akhir kegiatan.

\section{DAFTAR PUSTAKA}

Arifin T. 2008. Akuntabilitas dan keberlanjutan pengelolaan kawasan terumbu karang di Selat Lembeh Kota Bitung. [Disertasi]. Bogor (ID): Institut Pertanian Bogor.

Bato M, Yulianda F, Fahruddin A. 2013. Kajian manfaat kawasan konservasi perairan bagi pengembangan ekowisata bahari: Studi kasus di kawasan konservasi perairan Nusa Penida, Bali. Depik. 2(2): 104-113.

[BPS] Badan Pusat Statistik Kabupaten Sumbawa. 2016. Kecamatan Utan Dalam Angka 2015. Sumbawa (ID): BPS Kabupaten Sumbawa.

Barr S, Gilg AW. 2007. A conceptual framework for understanding and analyzing attitudes towards environmental behaviour. Geografiska Annaler: Series B, Human Geography. 89(4): 361-379. https://doi.org/ 10.1111/j.1468-0467.2007.00266.x

Collins JH. 2008. Marine tourism in the Kimberly Region of Western Australia. Geographical Research. 46(1): 111-123. https://doi.org/ 10.1111/j.1745-5871.2007.00496.x

Damanik J, Weber HF. 2006. Perencanaan Ekowisata: Dari Teori ke Aplikasi. Yogyakarta (ID): Penerbit Andi.

[Depbudpar-WWF] Departemen Kebudayaan dan Pariwisata-World Wildlife Fund. 2009. Prinsip dan Kriteria Ekowisata Berbasis Masyarakat. Jakarta (ID): Departemen Kebudayaan dan Pariwisata.

[DKP] Dinas Kelautan dan Perikanan Kabupaten Sumbawa. 2014. Laporan Tahunan Dinas Kelautan dan Perikanan Kabupaten Sumbawa. Dinas Kelautan dan Perikanan Kab Sumbawa. Sumbawa (ID).

Oguz D, Cakıcı I, Kavas S. 2011. Environmental awareness of students in higher education. SDU Faculty of Forestri Journal. 12: 34-39.

Hardianti S, Muhammad H, Lutfi M. 2015. Partisipasi masyarakat dalam pembangunan infrastruktur desa (program alokasi dana desa di Desa Buntongi Kecamatan Ampana Kota). Jurnal Katalogis. 5(1): 120-126.

Huraira A. 2008. Pengorganisasian dan pengembangan masyarakat: Model dan 
Starategi Pembangunan berbasis kerakyatan. Bandung (ID): Humaniora.

Joshi RL. 2011. Eco-tourism Planning and Management On Eco-tourism Destinations of Bajhang District, Nepal. A Term Paper: M. Sc. Forestry (2010-2012), p.11. Online [Available]: http://www.forestrynepal.org/ images/publications/Ecotourism $\quad \% 20$ destination \%20bajhang.pdf.

Kautsari N, Syafikri D. 2017. Iptek bagi masyarakat kelompok pembudidaya rumput laut di Desa Labuhan Sangoro yang mengalami kendala ketersediaan bibit. Agrokreatif Jurnal Ilmiah Pengabdian kepada Masyarakat. 3(1): 1-8. https://doi.org/10.29244/agrokreatif. 3.1.1-8

Kautsari N, Ahdiansyah Y. 2016. Daya dukung dan kesesuaian lahan perairan labuhan terata, sumbawa untuk pengembangan budi daya rumput laut. Ilmu Kelautan. 20(4): 233-238. https://doi.org/10.14710/ik.ijms.20.4.233238

Laksana NP. 2013. Bentuk-bentuk partisipasi masyarakat desa dalam program desa siaga di Desa Bandung, Kecamatan Playen, Kabupaten Gunung Kidul, Provinsi Daerah Istimewa Yogyakarta. Kebijakan dan Manajemen publik. 1(1): 56-66.

Liu J, Qu H, Huang D, Chen G, Yue X, Zhao X, Liang Z. 2014. The role of social capital in encouraging residents' pro-environmental behaviors in communitybased ecotourism. Tourism Management. 41: 190-201.

Munoz J, Pelegrin YF, Robledo D. 2004. Mariculture of Kappaphycus alvarezii (Rhodophyta, Solieriaceae) Color Strains in Tropical Waters of Yucatan, Mexico. Aquaculture. 239(1-4): 161-177. https://doi.org/10.1016/j.aquaculture.2004. 05.043

Radiarta N. 2013. Model penerapan iptek pengembangan kebun bibit rumput laut,
Kappaphycus alvarezii, di Kabupaten Minahasa Utara, Sulawesi Utara. Media Akuakultur. 8(1): 49-56. https://doi.org/ 10.15578/ma.8.1.2013.49-56

Radiarta IN, Saputra A, Priyono B. 2004. Pemetaan kelayakan lahan untuk pengembangan usaha budidaya laut di Teluk Saleh, Nusa Tenggara Barat. Jurnal Penelitian Perikanan Indonesia. 10(5): 19-32. http://dx. doi.org/10.15578/jppi.10.5.2004.19-32

Setyawan L, Satria A. 2017. Hubungan pengembangan wisata dengan strategi Nafkah dan taraf hidup rumah tangga nelayan Desa Karimunjawa. Jurnal Sains Komunikasi dan Pengembangan Masyarakat. 1(2): 167-182. https://doi.org/10.29244/jskpm.1.2.167-182

Tewari A, Eswaran K, Rao PVS, Jha BK. 2006. Is Kappaphycus alvarezii Heading Towards Marine Bioinvasion?. Current Science. 90(5): 619-620.

[TIES] The International Ecoturism Society. 2015. What is Ecotourism. [internet] [diunduh 31 Aug 2015]. Tersedia pada: https:// www. ecotourism. org / what -is-ecotourism.

Vicente-Molina MA, Fernandez-Sainz A, IzagirreOlaizola J. 2013. Environmental knowledge and other variables affecting proenvironmental behaviour: comparison of university students from emerging and advanced countries. Journal of Cleaner Production. 61: 130-138. https://doi.org/ 10.1016/j.jclepro.2013.05.015

[WWF] World Wide Fund. 2014. Budi daya Rumput Laut. Jakarta (ID): WWF-Indonesia.

Zhang H, Lei SL. 2012. A structural model of residents' intention to participate in ecotourism: the case of a wetland community. Tourism Management. 33(4): 916-925. https://doi.org/10.1016/j.tourman.2011.09. 012 